\title{
Perbandingan Pendapatan Usahatani Bawang Merah Dengan dan Tanpa Teknologi Feromon (Studi Kasus di Gapoktan Asta Mandiri, Desa Songan B, Kecamatan Kintamani, Kabupaten Bangli)
}

\author{
KETUT SWASTIKA, I GUSTI AGUNG AYU AMBARAWATI, \\ IDA AYU LISTIA DEWI
}
Program Studi Agribisnis, Program Non Reguler, Fakultas Pertanian, Universitas Udayana J1. PB Sudirman 80232 Denpasar
Email: swastikakt2794@gmail.com
annie_ambarawati@unud.ac.id

\begin{abstract}
The Comparison of Shallot Farming Income by Using and without Pheromone Technology (Case Study at the Association of Asta Mandiri Farmer Groups, Songan B Village, Kintamani District, Bangli Regency)
\end{abstract}

The main problem faced by farmers in shallot cultivation is the pest attack from worms. Farmers mostly control the pest by using high doses of chemical insecticide spraying. Pheromone technology is a breakthrough technology that can be used to control worm pest in shallot farming, heading to less use of insecticides. This research took place at the Association of Asta Mandiri Farmer Groups, Songan B Village, Kintamani District, Bangli Regency which was conducted from April to May 2016. The purpose of this study was to compare the shallot farming income using pheromone technology and without pheromone technology and the obstacles faced by farmers in applying the technology. Data were analyzed using analysis of farm income, the $\mathrm{R} / \mathrm{C}$ ratio, and t-test. The results showed that the income of shallot farming with pheromone technology was at Rp 97,597,413.38 per hectare per season, whereas without pheromone technology at $\mathrm{Rp} 78,605,563.89$ per hectare per season.The R/C ratio of shallot farming by using pheromones technology was 2,39 , whereas without the pheromone technology was 2,06. Based on t-test analysis, there is significantly difference in income at $95 \%$ level of confidence. Obstacles faced by farmers in applying pheromone technology, namely difficulties to obtain the pheromones in the market. It is expected that the government will provide the pheromones massively, so that farmers are able to apply the technology sustainably.

Keywords: farmincome, pheromone technology, obstacles, shallot

\section{Pendahuluan}

\subsection{Latar Belakang}

Salah satu komoditas pertanian yang berpotensi ekonomis untuk dikembangkan adalah tanaman bawang merah. Bawang merah adalah tanaman 
sayuran semusim yang memiliki nilai ekonomis tinggi dan dapat dikembangkan di wilayah dataran rendah sampai tinggi.Bawang merah dibutuhkan oleh konsumen rumah tangga, restoran, hotel, dan industri pengolahan makanan sebagai pelengkap bumbu masak (Arya dkk, 2015).

Masalah utama yang dihadapi oleh petani dalam budidaya bawang merah adalah serangan Organisme Pengganggu Tanaman (OPT) yaitu hama ulat bawang (Spodoptera exigua). Hama ini merupakan hama utama di sentra produksi bawang merah.Hasil kajian Thamrin, dkk (2003) di Sulawesi Selatan menunjukkan bahwaS. exigua merupakan hama dominan pada pertanaman bawang merah. Moekasan, dkk (2005) menyatakan bahwa kehilangan hasil panen akibat serangan ulat bawang dapat mencapai $100 \%$ jika tidak dilakukan upaya pengendalian karena hama ini bersifat polifagyaitu hama yang dapat memakan berbagai jenis tanaman dalam berbagai famili.

Petani di Gapoktan Asta Mandiri biasanya mengendalikan S. exigua dengan menyemprotkan insektisida kimiawi dosis tinggi. Penyemprotan dilakukan tiga hari sekali agar tanaman aman dari serangan ulat bawang. Penggunaan insektisida yang intensif dapat menyebabkan hama menjadi resisten terhadap insektisida yang digunakan, penggunaan insektisida untuk mengendalikan hama juga dapat mengurangi keragaman sehingga menyebabkan peledakan hama (Negara, 2003). Selain meningkatkan biaya pengendalian, penggunaan pestisida secara berlebihan berdampak kurang baik terhadap lingkungan, serta menimbulkan residu yang berlebih pada produk sehingga mengganggu kesehatan (Moekasan, 2012). Perlu ada terobosan teknologi dalam pengendalian hama ulat bawang antara lain yaitu dengan menggunakan teknologi feromon.

Teknologi feromon telah dikembangkan dan dikaji baik dalam skala laboratorium maupun lapang. Penerapan teknologi feromon dapat mengurangi penggunaan insektisida, menurunkan biaya produksi sampai Rp 2.000.000 per hektar dibandingkan dengan tanpa menggunakan feromon yang mencapai Rp4.000.000 s.d Rp 6.000.000 per hektar, mengurangi intensitas serangan hama hingga $8 \%$ dibanding dengan tanpa feromon intensitas serangan hama mencapai $25 \%$, produksi meningkat, yang pada gilirannya meningkatkan pendapatan petani (Samudra, 2006). Feromon berpeluang untuk dikembangkan pada areal yang lebih luas, terutama pada sentra produksi bawang merah dan endemis serangan hama ulat bawang (Badan Penelitian dan Pengembangan Pertanian, 2007).

\subsection{Tujuan Penelitian}

Berdasarkan uraian pada latar belakang tersebut, tujuan penelitian ini yaitu untuk mengetahui perbandingan pendapatan usahatani bawang merah dengan menggunakan teknologi feromon dan tanpa teknologi feromon, serta kendala-kendala yang dihadapi oleh petani yang menerapkan teknologi feromondi Gapoktan Asta Mandiri, Desa Songan B, Kecamatan Kintamani, Kabupaten Bangli. 


\section{Metode Penelitian}

\subsection{Lokasi dan Waktu Penelitian}

Penelitian ini dilakukan di Gapoktan Asta Mandiri, Desa Songan B, Kecamatan Kintamani, Kabupaten Banglipada bulan April sampai dengan bulan Mei tahun 2016. Pemilihan lokasi penelitian dilakukan secara purposive sampling, yaitu penentuan lokasi secara sengaja dengan dasar pertimbangan bahwa Desa Songan B, Kecamatan Kintamani, Kabupaten Bangli merupakan sentra penghasil bawang merah di Provinsi Bali, danpetani di Gapoktan Asta Mandiri telah menerapkan teknologi feromon dalam usahatani bawang merah.

\subsection{Populasi dan Sampel}

Populasi merupakan kumpulan individu atau objek penelitian yang memiliki ciri-ciri yang telah ditetapkan. Sampel atau responden adalah bagian dari populasi yang memiliki karakteristik yang relatif sama dan dianggap bisa mewakili populasi (Hakim, 2004). Populasi dalam penelitian ini adalah seluruh petani yang membudidayakan bawang merah dan tergabung dalam anggota Gapoktan Asta Mandiri, Desa Songan B, Kecamatan Kintamani, Kabupaten Bangli yaitu 174 petani yang terdiri atas 30 petani dengan menggunakan teknologi feromon dan 144 petani yang tidak menggunakan teknologi feromon. Pengambilan sampel atau responden dilakukan secara sensus yaitu semua petani yang menerapkan teknologi feromon diambil sebagai sampel/responden sebanyak 30 orang dan 30 orang yang tidak menggunakan teknologi feromon.

\subsection{Metode Pengumpulan Data, Variabel Penelitian, dan Metode Analisis Data}

Pengumpulan data dilakukan dengan cara observasi/pengamatan, wawancara dengan seluruh responden, dan wawancara mendalam dengan informan kunci. Variabel dalam penelitian ini mencakup perbandingan pendapatan usahatani bawang merah dengan menggunakan teknologi feromon dan tanpa teknologi feromon, serta kendala-kendala yang dihadapi oleh petani yang menerapkan teknologi feromon. Perbandingan pendapatan usahatani bawang merah dengan menggunakan teknologi feromon dan tanpa teknologi feromon dihitung dengan metode analisis deskriptif kualitatif dankendala-kendala yang dihadapi oleh petani yang menerapkan teknologi feromon dianalisis dengan metode deskriptif kualitatif berdasarkan uraian dan penjelasannya.

\section{Hasil dan Pembahasan}

3.1 Pendapatan Usahatani Bawang Merah dengan Menggunakan Teknologi Feromon

\subsubsection{Biayausahatani}

Besarnya biaya usahatani bawang merah sangat tergantung dari kegiatan kerja yang dilakukan selama proses penanaman sampai panen. Tahapan kerja dalam usahatani bawang merah baik yang menggunakan teknologi feromon ataupun tanpa 
teknologi feromon sama yaitu (1) mengolah tanah (2 minggu sebelum tanam), (2) memupuk dengan pupuk dasar (1 minggu sebelum tanam), (3) memasang mulsa plastik (1-2 hari sebelum tanam), (4) menanam benih bawang merah, (5) pemupukan I (10-15 HST), (6) pemupukan susulan II (20-25 HST), (7) pemupukan susulan III (30-35 HST), (8) mengendalikan OPT (7 HST), (9) mengairi atau menyiram tanaman (1-60 HST), (10) panen bawang merah (60-70 HST), dan (11) menjual bawang merah (1 minggu setelah panen atau setelah bawang dalam keadaan kering).

Biaya usahatani merupakan biaya yang dikeluarkan oleh seorang petani dalam melakukan proses produksi sampai menghasilkan produk (dari awal pengolahan lahan sampai panen dan menjual bawang merah). Pada penelitian ini biaya usahatani dibedakan menjadi dua, yaitu biaya tetap (fixed cost) dan biaya tidak tetap (variable cost) (Soekartawi, 2006). Biaya tetap dalam penelitian ini yaitu pajak, iuran kelompok tani, biaya kegiatan upacara agama, dan penyusutan alat-alat pertanian (mesin penyedot air, pipa air, selang, cangkul, sabit, hand sprayer, sepatu boot, toples feromon dan terpal). Biaya tidak tetap meliputi biaya tenaga kerja, biaya pembelian benih, pupuk, bahan bakar untuk menyedot air, mulsa plastik, feromon dan obat-obatan. Total jumlah biaya tenaga kerja usahatani bawang merah dengan menggunakan teknologi feromon yaitu Rp 18.403.916,67/LLG/MT. Biaya tenaga kerja dibagi menjadi dua yaitu tenaga kerja dalam keluarga sebesar 44,42\% dari total biaya tenaga kerja dan tenaga kerja luar keluarga 55,58\% dari total biaya tenaga kerja. Biaya tenaga kerja dalam keluarga sebesar $81,75 \mathrm{HOK}$ atau setara Rp 8.174.583,33. Tenaga kerja luar keluarga terdiri dari tenaga kerja harian $\mathrm{Rp}$ 2.930.000 dan tenaga kerja borongan $\operatorname{Rp} 7.299 .333,33$.

Total biaya usahatani bawang merah dengan menggunakan teknologi feromon yaitu Rp 70.207.000,96/LLG/MT. Total biaya usahatani terdiri dari biaya tetap sebesar Rp 469.083,96 (0,67\%) dan biaya tidak tetap Rp 69.737 .917 (99,33\%).

\subsubsection{Penerimaan dan pendapatan usahatani}

Penerimaan usahatani adalah jumlah produksi total usahatani dalam jangka waktu tertentu dikalikan dengan harga bawang merah yang berlaku. Pada saat penelitian petani menikmati harga yang cukup tinggi sebesar Rp 30.000/kg, namun dalam analisis ini dipakai harga rata-rata $\mathrm{Rp} 16.000 / \mathrm{kg}$. Rata-rata produksi bawang merah yang dihasilkan dari penggunaan teknologi feromon adalah $10.479 \mathrm{~kg} / \mathrm{ha}$ dikalikan dengan harga bawang merah $\mathrm{Rp}$ 16.000/kg maka diperoleh penerimaan sebesar Rp 167.664.000/ha/MT.Rata-rata pendapatan usahatani yang menggunakanteknologi feromon yaitu Rp 97.597.413,38/ha/MT yang diperoleh dari selisih penerimaan usahatani ( $\mathrm{Rp}$ 167.664.000) dengan total biaya usahatani ( $\mathrm{Rp}$ 70.066.586,62). Data selengkapnya tersaji pada tabel 1 . 
Tabel 1.

Rata-rata Penerimaan dan Pendapatan Usahatani per Luas Lahan Garapan (LLG) dan per Hektar dalam Satu Musim Tanam Usahatani Bawang Merah dengan Teknologi

Feromon di Gapoktan Asta Mandiri, Tahun 2016

\begin{tabular}{llcc}
\hline \multirow{2}{*}{ No } & \multicolumn{1}{c}{ Uraian } & \multicolumn{2}{c}{$\begin{array}{c}\text { Usahatani Bawang Merah dengan } \\
\text { Teknologi Feromon }\end{array}$} \\
\cline { 3 - 4 } & & 10.500 & per ha \\
\hline 1 & Produksi (kg) & 16.000 & 10.479 \\
2 & Harga (Rp) & 168.000 .000 & 16.000 \\
3 & Penerimaan (Rp) & $469.083,96$ & $468.145,79$ \\
4 & Total biaya tetap (Rp) & 69.737 .917 & $69.598 .440,83$ \\
5 & Total biaya tidak tetap (Rp) & $70.207 .000,63$ & $70.066 .586,62$ \\
6 & Total biaya (Rp) & $97.792 .999,38$ & $97.597 .413,38$ \\
\hline & Pendapatan Usahatani & 2,39 & 2,39 \\
\hline
\end{tabular}

\subsection{Pendapatan Usahatani Bawang Merah Tanpa Menggunakan Teknologi Feromon}

\subsubsection{Biaya usahatani}

Total biaya tenaga kerja usahatani bawang merah tanpa teknologi feromon yaitu Rp 17.703.208,33/LLG/MT. Biaya tenaga kerja dibagi menjadi dua yaitu tenaga kerja dalam keluarga sebesar 47,51 \% dari total biaya tenaga kerja dan tenaga kerja luar keluarga 52,49 \% dari total biaya tenaga kerja. Tenaga kerja dalam keluarga 84,1 HOK atau setara Rp 8.410.208,33. Tenaga kerja luar keluarga terdiri dari tenaga kerja harian Rp 2.520.000dan tenaga kerja borongan Rp 6.773.000.

Total biaya usahatani bawang merah tanpa menggunakan teknologi feromon yaitu Rp 68.750.173,13/LLG/MT. Total biaya usahatani terdiri dari total biaya tetap sebesar Rp 439.298,13 (0,64\%)dan total biaya tidak tetap Rp 68.310 .875 (99,36\%).

\subsubsection{Penerimaan dan pendapatan usahatani}

Penerimaan usahatani bawang merah tanpa menggunakan teknologi feromon sebesar Rp 152.512.000/ha/MT yang diperoleh dari perkalian antara rata-rata produksi bawang merah $(9.532 \mathrm{~kg} / \mathrm{ha})$ dengan harga bawang merah $\mathrm{Rp}$ 16.000/kg.Rata-rata pendapatan usahatanitanpamenggunakan teknologi feromon yaitu Rp78.605.563,89/ha/MT yang diperoleh dari selisih antara penerimaan usahatani sebesarRp 152.512.000dengan total biaya usahatani yaitu sebesar Rp 73.906.436,11. Data selengkapnya tersaji pada tabel 2. 
Tabel 2.

Rata-rata Penerimaan dan Pendapatan Usahatani per Luas Lahan Garapan (LLG) dan per Hektar dalam Satu Musim Tanam Usahatani Bawang Merah tanpa Teknologi

Feromon di Gapoktan Asta Mandiri, Tahun 2016

\begin{tabular}{llcc}
\hline \multirow{2}{*}{ No } & \multicolumn{1}{c}{ Uraian } & \multicolumn{2}{c}{$\begin{array}{c}\text { Usahatani Bawang Merah tanpa } \\
\text { Teknologi Feromon }\end{array}$} \\
\cline { 3 - 4 } & & per LLG $(0,928$ ha) & per ha \\
\hline 1 & Produksi (kg) & 16.067 & 9.532 \\
2 & Harga (Rp) & 141.868 .004 & 16.000 \\
3 & Penerimaan (Rp) & $439.298,13$ & 472.512 .000 \\
4 & Total biaya tetap (Rp) & 68.310 .875 & 73.434 .191 \\
5 & Total biaya tidak tetap (Rp) & $68.750 .173,13$ & $73.906 .436,11$ \\
6 & Total biaya (Rp) & $73.117 .830,66$ & $78.605 .563,89$ \\
\hline & Pendapatan Usahatani & 2,06 & 2,06 \\
\hline
\end{tabular}

\subsection{Perbandingan Pendapatan Usahatani Bawang Merah dengan Menggunakan Teknologi Feromon dan tanpa Teknologi Feromon}

\subsubsection{Perbandingan secara riil}

Rata-rata pendapatan usahatani yang diterima oleh responden usahatani bawang merah dengan menggunakan teknologi feromon (Rp 97.597.413,38/ha/MT) lebih besar dibandingkan dengan responden usahatani bawang merah tanpa teknologi feromon ( $\mathrm{Rp} 78.605 .563,89 / \mathrm{ha} / \mathrm{MT}$ ). Hal tersebut disebabkan oleh produksi usahatani bawang merah dengan menggunakan teknologi feromon $(10.479 \mathrm{~kg} / \mathrm{ha})$ lebih besar dibandingkan dengan usahatani bawang merah tanpa teknologi feromon (9.532 kg/ha). Total biaya usahatani bawang merah dengan menggunakan teknologi feromon (Rp 70.066.586,62/ha/MT) lebih rendah dari usahatani bawang merah tanpa teknologi feromon ( $\mathrm{Rp} 73.906 .436,11 / \mathrm{ha} / \mathrm{MT})$, sehingga hal tersebut berpengaruh terhadap pendapatan yang diterima. Selisih antara pendapatan usahatani bawang merah dengan menggunakan teknologi feromon dan tanpa teknologi feromon yaitu sebesar Rp18.991.849,49/ha/MT pada tingkat harga yang sama (Rp 16.000/kg). Data selengkapnya tersaji pada tabel 3. 
Tabel 3.

Perbandingan Rata-rata Pendapatan Usahatani Bawang Merah per Hektar di Gapoktan Asta Mandiri, Tahun 2016

\begin{tabular}{|c|c|c|c|}
\hline \multirow[t]{2}{*}{ No } & \multirow[t]{2}{*}{ Uraian } & \multicolumn{2}{|c|}{ Usahatani Bawang Merah } \\
\hline & & $\begin{array}{c}\text { Dengan Teknologi } \\
\text { Feromon }\end{array}$ & $\begin{array}{c}\text { Tanpa Teknologi } \\
\text { Feromon }\end{array}$ \\
\hline 1 & Produksi $(\mathrm{kg})$ & 10.479 & 9.532 \\
\hline 2 & Harga $(R p)$ & 16.000 & 16.000 \\
\hline 3 & Penerimaan (Rp) & 167.664 .000 & 152.512 .000 \\
\hline 4 & Total biaya tetap (Rp) & $468.145,79$ & $472.245,48$ \\
\hline 5 & Total biaya tidak tetap ( $\mathrm{Rp})$ & $69.598 .440,83$ & 73.434 .191 \\
\hline 6 & Total biaya (Rp) & $70.066 .586,62$ & $73.906 .436,11$ \\
\hline & Pendapatan Usahatani & $97.597 .413,38$ & $78.605 .563,89$ \\
\hline & R/C Ratio & 2,39 & 2,06 \\
\hline & Uji-t & \multicolumn{2}{|c|}{$\begin{array}{l}\text { F-hitung }=1,148 \\
\text { Signifikansi }=0,288 \\
\text { t-hitung }=1,985 \\
\text { Derajat Bebas }(d f)=58 \\
\text { t-tabel }(\alpha=1 \%)=2,423 \\
\text { t-tabel }(\alpha=5 \%)=1,684\end{array}$} \\
\hline
\end{tabular}

\subsubsection{Perbandingan $R / C$ ratio}

Berdasarkan tabel 3, terlihat bahwa $\mathrm{R} / \mathrm{C}$ ratio usahatani bawang merah dengan menggunakan teknologi feromon per hektar dalam satu musim tanam sebesar 2,39. Hal ini berarti bahwa setiap $\mathrm{Rp} 1.000$ modal yang diinvestasikan untuk usahatani bawang merah dengan menggunakan teknologi feromon memberikan penerimaan sebesar $\mathrm{Rp}$ 2.390. R/C ratio usahatani bawang merah tanpa teknologi feromon per hektar dalam satu musim tanam sebesar 2,06 yang artinya setiap Rp 1.000 modal yang diinvestasikan untuk usahatani bawang merah tanpa menggunakan teknologi feromon akan menghasilkan penerimaan sebesar $\mathrm{Rp}$ 2.060.Usahatani bawang merah baik yang menggunakan teknologi feromon dan tanpa teknologi feromon di Gapoktan Asta Mandiri sama-sama menguntungkan ( $\mathrm{RC}>1$ ), namun yang memberikan penerimaan lebih tinggi adalah usahatani dengan menggunakan teknologi feromon, karena $\mathrm{R} / \mathrm{C}$ rationya lebih besar dibandingkan dengan tanpa teknologi feromon yaitu sebesar Rp 330 untuk setiap Rp 1.000 yang dikeluarkan sebagai biaya.

\subsubsection{Analisis uji-t}

Analisis uji-t digunakan untuk menganalisis uji beda nyata pendapatan usahatani bawang merah dengan menggunakan teknologi feromon dan tanpa teknologi feromon. Uji beda nyata yang digunakan dalam analisis dengan uji-t yaitu dengan aplikasi komputer menggunakan SPSS 17 (Kadir, 2015). 
Berdasarkan tabel 3, hasil analisis uji beda rata-rata diperoleh nilai t-hitung sebesar 1,985 yang lebih besar dari t-tabel $\alpha=5 \%(1,684)$ yang artinya secara uji statistik rata-rata pendapatan usahatani bawang merah dengan menggunakan teknologi feromondantanpa teknologi feromon per hektar per musim tanam berbeda nyata.

Selain meningkatkan pendapatan, ada pun keuntungan lain yang diperoleh oleh responden yang telah menggunakan teknologi feromon yaitu sebagai berikut.

1) Penggunaan teknologi feromon mampu mengendalikan hama ulat bawang, terbukti dari berkurangnya aktivitas pengendalian hama yang dilakukan oleh responden. Responden dengan teknologi feromon melakukan penyemprotan insektisida sebanyak enam kali dalam satu musim tanam, sedangkan responden tanpa teknologi feromon melakukan penyemprotan sebanyak 11 kali per musim tanam.

2) Penggunaan teknologi feromon dapat mengurangi biaya pengendalian hama. Biaya pengendalian hama yaitu biaya tenaga kerja pengendalian hama dan biaya pembelian insektisida. Responden yang telah menggunakan teknologi feromon mengeluarkan biaya tenaga kerja pengendalian hama sebesar Rp 509.811,7/ha/MT, sedangkan responden tanpa teknologi feromon sebesar Rp 1.048.125/ha/MT (51,36\% lebih tinggi). Responden yang telah menggunakan teknologi feromon mengeluarkan biaya pembelian insektisida dan pembelian feromon sebesar Rp1.594.305/ha/MT, sedangkan tanpa teknologi feromon mengeluarkan biaya pembelian insektisida sebesar $\mathrm{Rp} 4.871 .542 / \mathrm{ha} / \mathrm{MT}$ $(67,27 \%$ lebih tinggi).

3) Berkurangnya aktivitas pengendalian hama dan penggunaan insektisida berdampak positif yaitu menghindari pencemaran lingkungan dan menjaga keragaman, sehingga dapat menghasilkan produk bawang merah yang lebih sehat dan aman untuk dikonsumsi.

\subsection{Kendala-kendala Petani Bawang Merah yang Menerapkan Teknologi Feromon}

Seluruh responden usahatani bawang merah yang telah menggunakan teknologi feromon di Gapoktan Asta Mandiri pada musim tanam Desember 2015 sampai dengan Januari 2016, mengatakan bahwa penggunaan teknologi feromon dari segi sosial dapat diterima, kemudian dari segi ekonomi menguntungkan petani. Keuntungan yang dirasakan oleh responden yaitu teknologi feromon dapat menghemat biaya tenaga kerja pengendalian hama sebesar Rp 538.314/ha/MT $(0,73 \%$ dari total biaya), menghemat pembelian pestisida sebesar Rp 3.277.237/ha/MT (4,43\% dari total biaya). Berkurangnya penggunaan pestisida, secara sosial berdampak baik terhadap kesehatan petani dan konsumen bawang merah, serta dapat mengurangi pencemaran lingkungan.

Secara teknis petani tidak mengalami kesulitan dalam mengaplikasikan teknologi feromon. Alat-alat yang dibutuhkan seperti toples, tali rafia dan potongan 
bambu, semuanya bisa diperoleh dengan mudah oleh petani. Kendala yang dihadapi oleh petani bawang merah yang telah menggunakan teknologi feromon yaitu kendala non teknis, dimana pada saat ini masih sulit mendapatkan feromon dipasaran. Feromon yang telah digunakan oleh petani di Gapoktan Asta Mandiri adalah bantuan yang diberikan oleh BPTPH (Balai Perlindungan Tanaman Pangan dan Hortikultura) Provinsi Bali. Ketersediaan feromon yang masih terbatas menyebabkan petani sulit menerapkan teknologi feromon secara berkelanjutan.

\section{Simpulan dan Saran}

\subsection{Simpulan}

Berdasarkan hasil analisis yang telah dilakukan dapat ditarik kesimpulan sebagai berikut.

1. Pendapatan usahatani bawang merah dengan menggunakan teknologi feromon di Gapotan Asta Mandiri, Desa Songan B, Kecamatan Kintamani Kabupaten Bangli lebih besar dibandingkan dengan usahatani bawang merah tanpa teknologi feromon. Pendapatan usahatani dengan teknologi feromonsebesar Rp 97.597.413,38/ha/MT, sedangkan usahatani tanpa teknologi feromon sebesar Rp 78.605.563,89/ha/MT.R/C ratio usahatani dengan teknologi feromon yaitu 2,39, sedangkan usahatani tanpa teknologiferomon yaitu 2,06.Berdasarkan hasil analisis uji-t terdapat perbedaan nyata antara pendapatan usahatani bawang merah yang menggunakan teknologi feromon maupun tanpa teknologi feromon.

2. Kendala yang dihadapi oleh petani bawang merah di Gapoktan Asta Mandiri yang telah menggunakan teknologi feromon yaitu sulit mendapatkan feromon dipasaran. Feromon saat ini belum dijual secara massal sehingga petani tidak bisa menerapkan teknologi feromon secara berkelanjutan.

\subsection{Saran}

Berdasarkan hasil penelitian yang diperoleh yaitu bahwa teknologi feromon mampu mengurangi tingkat serangan hama ulat bawang, mengurangi biaya pengendalian hama dan meningkatkan pendapatan usahatani, namun karena ketersediaannya terbatas maka pemerintah diharapkan dapat menyediakan feromon secara massal, sehingga petani bawang merah tidak kesulitan untuk menggunakan teknologi feromon secara berkelanjutan.

\section{$5 \quad$ Ucapan Terima Kasih}

Penulis mengucapkan banyak terima kasih kepada anggota Gapoktan Asta Mandiri yang telah memberikan informasi kepada penulis selama melakukan penelitian.

\section{Daftar Pustaka}

Arya, Nyoman Ngurah, I Ketut Mahaputra, I Putu Sugiarta, Hadis Jayanti, Suharyanto, Jemmy Rinaldi. 2015. Rencana Operasional Diseminasi Hasil 
Penelitian: Pendampingan Pengembangan Kawasan Komoditas Bawang Merah. Balai Pengkajian Teknologi Pertanian Bali. Denpasar.

Badan Penelitian dan Pengembangan Pertanian. 2007. Feromon Exi Sukses Kendalikan Ulat Bawang Merah di Cirebon. Badan Penelitian dan Pengembangan Pertanian, Jakarta.

Hakim, A. 2004. Statistik Deskriptif untuk Ekonomi dan Bisnis. Ekonosia. Jakarta.

Kadir. 2015. Statistika Terapan: Konsep, Contoh dan Analisis Data dengan Program SPSS/Lisrel dalam penelitian. PT Raja Grafindo Persada. Jakarta.

Moekasan, K.T. 2012. Penerapan Ambang Pengendalian Organisme Pengganggu Tumbuhan pada Budidaya Bawang Merah dalam Upaya Mengurangi Penggunaan Pestisida. Internet. Diunduh di http://www.ejurnal.litbang.pertanian.go.id. Diunduh pada Tanggal 16 Maret 2016.

Moekasan, K.T., L. Prabaningrum dan M.L. Ratnawati. 2005. Penerapan PHT pada Sistem Tanam Tumpang Gilir Bawang Merah dan Cabai. Monografi No. 19. Balai Penelitian Tanaman Sayuran Lembang.

Negara, A. 2003. Penggunaan Analisis Probit untuk Pendugaan Tingkat Kepekaan Populasi Spodoptera exigua terhadap Deltametrin di Daerah Istimewa Yogyakarta. Informatika Pertanian. Yogyakarta.

Samudra. 2006. Pengendalian Ulat Bawang Ramah Lingkungan. Warta Penelitian dan Pengembangan Pertanian.

Soekartawi. 2006. Analisis Usahatani. UI-Press. Jakarta.

Thamrin, M., Ramlan, Armiati, Ruchjaningsih, dan Wahdania. 2003. Pengkajian Sistem Usahatani Bawang Merah di Sulawesi Selatan. Pengkajian dan Pengembangan Teknologi Pertanian. 